\title{
PENINGKATAN KINERJA GURU DALAM MENYUSUN RENCANA PELAKSANAAN PEMBELAJARAN (RPP) INOVATIF MELALUI KERJA PRAKTEK DENGAN TEKNIK UMPAN BALIK DI SD NEGERI 165726 TEBING TINGGI
}

\author{
Betti \\ Surel : betti165726@gmail.com
}

\begin{abstract}
ABSTRAK
Tujuan penelitian ini adalah untuk meningkatkan kinerja guru SD Negeri 165726 Tebing Tinggi dalam menyusun RPP Inovatif. Peneliti/supervisor mengumpulkan masing-masing sebuah RPP yang telah dibuat guru. Kemudian dikaji dan dinilai, diberikan umpan balik berdasarkan 8 (delapan) komponen sesuai dengan format penilaian RPP dalam Panduan Penyusunan Perangkat Portofolio Sertifikasi Guru Dalam Jabatan, Direktorat Jnderal Pendidikan Tinggi (2007:36). Dari hasil-hasil yang dipaparkan, dapat dibuat simpulan bahwa hipotesis tindakan telah terbukti, Kegiatan Kerja Praktek dengan teknik Umpan Balik, terbukti dapat meningkatkan komitmen guru-guru SD Negeri 165726 Tebing Tinggi dalam menyusun RPP Inovatif. Indikator kinerja: Sekurang-kurangnya $85 \%$ guru menunjukkan komitmen yang baik dalam menyusun RPP Inovatif (nilai rata-rata 4,00-5,00) dalam skala 1-5, tercapai pada akhir siklus III dengan pencapaian $94 \%$.
\end{abstract}

Kata Kunci : Strategi Praktek Kerja, RPP Inovatif, Teknik Umpan Balik

\section{PENDAHULUAN}

Pendidikan yang mampu mendukung pembangunan di masa mendatang adalah pendidikan yang mampu mengembangkan potensi peserta didik, sehingga yang bersangkutan mampu memiliki dan memecahkan problema pendidikan yang dihadapinya. Sekolah sebagai suatu institusi atau lembaga pendidikan idealnya harus mampu melakukan proses edukasi, sosialisasi, dan transformasi. Dengan kata lain, sekolah yang bermutu adalah sekolah yang mampu berperan sebagai proses edukasi (proses pendidikan yang menekankan pada kegiatan mendidik dan mengajar), proses sosialisasi (proses bermasyarakat terutama bagi anak didik), dan wadah proses transformasi (proses perubahan tingkah laku ke arah yang lebih baik/ lebih maju).

Berlakunya Peraturan Menteri Pendidikan Nasional No.18 tahun 2007 tentang Sertifikasi Guru Dalam Jabatan mewajibkan guru untuk memiliki Sertifikat Pendidik melalui ujian Sertifikasi. Salah satu kompetensi yang dituntut adalah kompetensi pedagogik, dari merencanakan pembelajaran, melaksanakan pembelajaran, melaksanakan evaluasi dan analisis hasil evaluasi serta tindak lanjut. Dari puluhan guru yang berada di bawah binaan penulis tak seorangpun mampu menunjukkan dan menggunakan RPP sesuai dengan pedoman penilaian sertifikasi. Khusus di SD NEGERI 165726 tebing Tinggi mayoritas sudah

Guru SD Negeri 165726 Tebing Tinggi 
mendapatkan tunjangan sertifikasi. Namun tak satupun mampu menunjukkan RPP yang sesuai dengan pedoman sertifikasi. Pembuatan RPP adalah sangat penting dilakukan oleh seorang guru, menurut Hamzah B. Uno (2006:4) : Perbaikan kualitas pembelajaran haruslah diawali dengan perbaikan desain pembelajaran. Perencanaan Pembelajaran dapat dijadikan titik awal dari upaya perbaikan kualitas pembelajaran.

Beberapa faktor yang diduga sebagai penyebab terjadinya hal itu antara lain :

1) Kurangnya tuntutan supervisor (Kepala Sekolah dan Pengawas Sekolah), karena masih memperkenankan penggunaan RPP buatan Instansi atau orang lain, dengan anggapan bahwa karya bersama dan dalam tingkat yang lebih tinggi pasti lebih baik. Walau dalam kenyataan tidak selalu sesuai dengan kondisi sekolah masingmasing.

2) Selama ini guru-guru sudah memiliki kenyamanan tersendiri, karena telah ada RPP buatan Tim Dinas Kota Tebing Tinggi. Walau RPP (Rencana Pelaksanaan Pembelajaran) itu hanya ditunjukkan kepada pengawas sebagai bukti fisik. Namun, pelaksanaan di depan kelas berbeda dengan skenario yang tertulis dalam RPP tersebut. Untuk memenuhi tuntutan Peraturan Menteri Pendidikan Nasional No. 41 tahun 2007 yang mengubah paradigma proses pendidikan dari pengajaran menjadi pembelajaran dan mengubah strategi ekspositori menjadi diskoveri inkuiri, diperlukan model RPP baru yang selanjutnya dalam penelitian ini disebut "RPP INOVATIF". Alasan khusus bahwa penelitian ini dilakukan di SD NEGERI 165726 Tebing Tinggi karena sekolah tersebut adalah sekolah binaan penulis. Lain dari pada itu profil guru di sekolah ini memiliki beberapa keterbatasan dalam standar pendidik, yaitu sebanyak $31 \%$ guru-guru disini adalah guru non PNS. Masalah-masalah pokok dalam penelitian ini adalah :

1. Apakah Kerja Praktek dengan Teknik Umpan Balik dapat meningkatkan komitmen guruguru SD NEGERI 165726 Tebing Tinggi menyusun RPP Inovatif?

2. Apakah Kerja Praktek dengan Teknik Umpan Balik dapat meningkatkan kemampuan guruguru SD NEGERI 165726 Tebing Tinggi menyusun RPP Inovatif?

Penelitian ini bertujuan untuk mengetahui :

1) Peningkatan komitmen guruguru SD NEGERI 165726 Tebing Tinggi menyusun RPP Inovatif dalam kegiatan Kerja Praktek dengan teknik Umpan Balik. 
2) Peningkatan kemampuan guruguru SD NEGERI 165726 Tebing Tinggi menyusun RPP Inovatif dalam kegiatan Kerja Praktek dengan teknik Umpan Balik.

\section{METODE PENELITIAN}

Desain penelitian ini adalah Penelitian Tindakan model Stephen Kemmis. Penelitian dilaksanakan dalam enam bulan yaitu bulan Juli sampai dengan Desember 2015 .

Lokasi Penelitian adalah di SD NEGERI 165726 Tebing Tinggi. Subjek Penelitian adalah semua guru mata pelajaran di SD NEGERI 165726 Tebing Tinggi sebanyak 21 orang.

Objek penelitian ini adalah kemauan dan kemampuan guru-guru membuat RPP Inovatif. Sebagai variabel bebas adalah "strategi Kerja Praktek dengan teknik Umpan Balik", dan variabel terikat adalah "komitmen" dan "kemampuan" guru menyusun RPP Inovatif.

Penelitian ini direncanakan dalam 3 (tiga) siklus. Perencanaan penelitian dibagi dalam langkahlangkah sebagai berikut :

1) Observasi dan Refleksi Awal

Kegiatan ini dimaksudkan untuk mengetahui kemampuan awal guru-guru menyusun RPP sebelum dilaksanakan tindakan. Peneliti/supervisor mengumpulkan masing-masing sebuah RPP yang telah dibuat guru. Kemudian dikaji dan dinilai, diberikan umpan balik berdasarkan 8 (delapan) komponen sesuai dengan format penilaian RPP dalam Panduan Penyusunan Perangkat Portofolio Sertifikasi Guru Dalam Jabatan, Direktorat Jnderal Pendidikan Tinggi (2007:36) yaitu :

a) Kejelasan rumusan tujuan pembelajaran;

b) Pemilihan materi ajar;

c) Pengorganisasian materi ajar;

d) Pemilihan sumber/media pembelajaran

2) Siklus I

Siklus I ini terdiri dari beberapa tahapan yaitu :

a) Perencanaan, siklus pertama ini direncanakan terdiri dari :

- Pembentukan kelompok : Kelompok Rumpun Mata Pelajaran (Bahasa, MIPA, IPS dan lainnya), serta jadwal pertemuan ;

- Informasi : Tentang teknik perumusan langkah-langkah pembelajaran RPP Inovatif dengan pola konvensional, oleh supervisor (peneliti) ;

- Diskusi : Diskusi terbimbing dalam rumpun mata pelajaran. Bahan diskusi adalah RPP pertama yang telah dinilai dan diberi umpan balik ;

- Praktek : tugas terpantau (ditentukan batas waktunya) untuk merevisi RPP pertama, menjadi RPP yang lengkap sesuai format penilaian dalam sertifikasi ; 
b) Pelaksanaan tindakan, sesuai dengan jadwal dan rencana kegiatan yang telah ditentukan dalam perencanaan siklus I.

c) Observasi, berlangsung selama kegiatan (dalam proses) untuk:

- mengumpulkan data tentang komitmen guru dalam melaksanakan kegiatan,

- melakukan penilaian kemampuan guru dalam melakukan revisi RPP, melalui koleksi dokumen.

d) Refleksi, mengkaji hasil-hasil yang dicapai selama pelaksanaan tindakan, serta usaha dan rencana perbaikannya.

\section{3) Siklus II}

Siklus kedua ini, akan dilaksanakan seandainya hasil-hasil pada siklus I belum mencapai indikator kinerja. Kegiatan direncanakan terdiri dari beberapa tahapan yaitu :

a) Perencanaan, suklus kedua direncanakan terdiri dari :

- Informasi : Tentang teknik perumusan langkah-langkah pembelajaran RPP dengan pola Inovatif (mengadopsi modelmodel pembelajaran Inovatif) oleh peneliti ;

- Diskusi: terbimbing dalam rumpun mata pelajaran;

- Praktek : terpantau (ditentukan batas waktunya) untuk merevisi RPP perbaikan menjadi sebuah RPP yang Inovatif ;
- Presentasi : beberapa pertemuan lanjutan untuk memberikan kesempatan tiap-tiap guru mempresentasikan hasil kerjanya;

b) Pelaksanaan tindakan, sesuai dengan jadwal dan rencana kegiatan yang telah ditentukan dalam perencanaan siklus II.

c) Observasi, Sama seperti pelaksanaan pada siklus I,

- Mengumpulkan data tentang komitmen guru dalam melaksanakan kegiatan merevisi RPP.

- Melakukan penilaian kemampuan guru dalam menyusun RPP yang Inovatif melalui koleksi dokumen.

d) Refleksi, mengkaji hasil-hasil yang dicapai selama pelaksanaan tindakan, serta usaha dan rencana perbaikannya jika masih dipandang perlu.

4) Siklus III

Siklus III akan dilaksanakan seandainya hasil-hasil pada siklus II belum mencapai indikator kinerja, dengan bentuk kegiatan :

a) Perencanaan, siklus ketiga adalah pemberian tugas dengan target (ditentukan jumlah) RPP yang harus diselesaikan. Guruguru secara mandiri dalam kelompok melaksanakan diskusi tak terbimbing. Diharapkan tiap guru menghasilkan 1 (satu) buah RPP Inovatif ; 
b) Pelaksanaan tindakan, sesuai dengan jadwal dan rencana kegiatan yang telah ditentukan dalam perencanaan siklus III.

c) Observasi,

- Penilaian komitmen guru-guru melaksanakan kegiatan,

- Penilaian kemampuan guru dalam menyusun RPP yang Inovatif melalui koleksi dokumen.

d) Refleksi, mengkaji hasil-hasil yang dicapai selama pelaksanaan tindakan, dan melakukan analisis data untuk dapat menarik kesimpulan umum dari kegiatan siklus pertama, siklus kedua dan siklus ketiga.

Dengan memperhatikan kondisi awal guru-guru di SD NEGERI 165726 Tebing Tinggi :

1. Dari 3 orang guru senior SD NEGERI 165726 Tebing Tinggi yang mengikuti uji sertifikasi, bahwa ketiganya belum memiliki kemampuan menyusun RPP sesuai pedoman yang berlaku.

2. Masih banyak guru (sekitar 90\%) tidak mampu menyusun RPP atau tidak menggunakan RPP buatan sendiri dan mumnya RPP yang digunakan kurang Inovatif.

Maka, indikator kinerja dalam penelitian ini :

1. Sekurang-kurangnya $85 \%$ guru menunjukkan komitmen yang baik dalam menyusun RPP

Inovatif (nilai rata-rata 4,00$5,00)$ dalam skala 1-5.

2. Sekurang-kurangnya $85 \%$ guru menunjukkan kemampuan yang baik dalam menyusun RPP Inovatif (nilai rata-rata 4,00$5,00)$ dalam skala $1-5$.

\section{HASIL DAN PEMBAHASAN}

Kemampuan guru menyusun RPP sebelum tindakan dapat dinilai dari RPP awal yang dikumpulkan guru-guru. Rata-rata kemampuan seluruh guru (21 orang) adalah 1,52 dalam skala 1-5. Guru yang mampu meraih nilai 4,00-5,00 tidak ada (0\%) berdasarkan pedoman penilaian RPP dalam Panduan Penyusunan Perangkat Portofolio Sertifikasi Guru Dalam Jabatan (Direktorat Jenderal Pendidikan Tinggi Departemen Pendidikan Nasional).

Sesuai dengan Gleackman, komitmen mengandung komponen dorongan, usaha dan penyediaan waktu yang cukup banyak. Selanjutnya dalam penelitian ini komitmen dijabarkan menjadi : Dorongan (D1 = antusias, ingin tahu, tekun, dan D2 = konsentrasi, perhatian), Usaha (U1 = konfirmasi dan kontribusi, U2 = eksplorsi dan elaborasi, $\mathrm{U} 3=$ kooperatif dan kolaboratif, U4 = aktifitas dalam tugas/praktek/ presentasi), Penyediaan Waktu (W1 = hadir dalam setiap kegiatan, $\mathrm{W} 2=$ hadir/pulang tepat waktu, U3 = menyelesaikan tugas tepat waktu). 
Pada siklus I ada 2 orang guru pindah tugas, sehingga jumlah subjek menjadi 19 orang. Dari tabel terlihat guru-guru belum antusias dan dorongan belum kuat. Fakta itu terlihat dari lampiran 1d, yaitu :

Dorongan : Usaha

- D1 rata-rata 2,5

- U1 rata-rata 2,6

- U3 rata-rata 3,4

- D2 rata-rata 2,5

- U2 rata-rata 2,6

- U4 rata-rata 3,4

1. Nilai Rata-rata Komitmen dan

Persentase dengan nilai 4,00 - 5,00

BHS 3,17 $=20 \%$

MIPA 3,77=33\%

IPS 3,19=25\%

TTL 3,36 $=26 \%$

2. Nilai Rata-rata Kemampuan dan Persentase dengan nilai 4,00 - 5,00

BHS 2,46 $=20 \%$

MIPA 3,54=17\%

IPS $2,99=10 \%$

TTL $3,02=11 \%$

Keterangan

BHS = rumpun bahasa

MIPA = rumpun Matematika dan IPA

IPS = rumpun IPS

$\mathrm{TTL}=$ total

Pembahasan

Komitmen guru-guru :

1. Dari hasil wawancara dengan guru-guru, diketahui alasan mengapa guru-guru kurang antusias dan dorongan kurang kuat. Alasannya karena RPP sesuai dengan format sertifikasi guru dianggap bukan hal baru dan guru tidak merasa mendapat sesuatu yang baru.

2. Komponen komitmen yang nilainya baik pada siklus I adalah komponen waktu, yaitu hadir setiap kegiatan, hadir/pulang tepat waktu dan menyelesaikan tugas tepat waktu dengan nilai : W1 rata-rata 4,9; W2 rata-rata 4,6 dan W3 ratarata 3,9. Guru-guru yang dengan nilai komitmen 4,00-5,00 mencapai $26 \%$.

Kemampuan guru-guru :

1. Terjadi peningkatan nilai kemampuan dengan rata-rata nilai mencapai 3,02. Dari lampiran $6 \mathrm{~d}$, terlihat bahwa ada 2 orang guru $(=11 \%)$ yang telah mampu mencapai nilai lebih dari 4,00.

2. Dengan Pola Konvensional : pendekatan $\rightarrow$ strategi $\rightarrow$ metode $\rightarrow$ teknik, guru mengalami kesulitan menentukan metode untuk mendukung strategi diskoveri inkuiri. Ceramah, tanya jawab, demonstrasi, penugasan adalah metoda-metoda konvensional yang selalu digunakan guru.

3. Dari hasil wawancara diketahui penyebabnya, karena guru-guru 
belum paham dengan modelmodel pembelajaran Inovatif. Akibatnya guru-guru masih kesulitan mengubah strategi "ekspositori" manjadi "diskoveri inkuiri”.

4. Lain dari pada itu, seluruh RPP belum memunculkan Tugas Terstruktur dan Kegiatan Mandiri tak terstruktur, sehingga rata-rata untuk kelengkapan RPP baru mencapai 1,5 .

Refleksi :

Dari hasil-hasil siklus I, tampak ada peningkatan baik komitmen maupun kemampuan namun indikator kinerja belum tercapai. Maka diputuskan melaksanakan perencanaan siklus II. Memperhatikan hasil-hasil wawancara dengan guru, maka dalam siklus II akan lebih dimantapkan model-model pembelajaran Inovatif.

Komitmen dan Kemampuan Guru pada Siklus II

1. Nilai Rata-rata Komitmen dan

Persentase dengan nilai 4,00 - 5,00

BHS 4,01= 75\%

MIPA4, $13=83 \%$

IPS 3,69 $=63 \% \%$

TL $3,89=68 \%$

2. Nilai Rata-rata Kemampuan dan Persentase dengan nilai 4,00-5,00

BHS $4,20=100 \%$
MIPA $4,48=80 \%$

IPS $4,06=63 \%$

TTL $4,22=76 \%$

Keterangan :

BHS = rumpun bahasa

MIPA = rumpun MIPA

IPS = rumpun IPS

$\mathrm{TTL}=$ total

Pada sikkus II ada 2 orang lagi guru pindah tugas, sehingga jumlah subjek menjadi 17 orang.

Pembahasan

Komitmen guru-guru Setelah disajikan model-model pembelajaran Inovatif (cooperatif learning, contextual teaching and learning, dll), komitmen guru pada komponen dorongan dan usaha menunjukkan peningkatan yang cukup tinggi, mencapai nilai rata-rata lebih dari 3,6 (lihat lampiran 2d). Guru-guru yang memperoleh nilai 4,00-5,00 mencapai $68 \%$.

Dari hasil wawancara, bahwa guru-guru baru mengetahui bahwa begitu banyak model-model pembelajaran yang harus dipahami untuk berubah dari pendekatan ekspositori ke pendekatan diskoveri inkuiri.

Menurut guru-guru, ada peningkatan rasa ingin tahu yang mendorong mereka terus belajar. Alasannya, bahwa penerapan modelmodel pembejaran sangat memudahkan guru membuat RPP Inovatif karena syntax tiap-tiap 
model pembelajaran sudah sangat jelas. Guru-guru sangat terbantu dalam upaya membuat strategi pembelajaran yang berpusat pada siswa (student centre oriented) dengan pendekatan diskoveri inkuiri.

Motivasi guru-guru mulai tumbuh, karena model-model pembelajaran andragogi dengan bentuk kerja praktek sangat disukai oleh guru-guru. Menurut guru, itu jauh berbeda dengan model-model sebelumnya yang mengandalkan bentuk-bentuk ekspos fakto/ceramah.

Kemampuan guru-guru

Terjadi peningkatan nilai kemampuan yang cukup tinggi dari Siklus I ke Siklus II. Pada lampiran $7 \mathrm{~d}$, terlihat rata-rata kemampuan guru meningkat menjadi 4,22 dan hanya 4 orang dari 17 orang guru yang nilainya masih kurang dari 4,00. Pada akhir siklus II, guru-guru yang memperoleh nilai $4,00-5,00$ meningkat tajam mencapai $76 \%$. Hal itu didukung oleh hasil-hasil wawancara dengan guru, bahwa guru-guru merasa sangat mudah menyusun RPP Inovatif karena telah memahami model-model pembelajaran dengan syntaxsyntaxnya.

Dari hasil-hasil siklus II, tampak ada peningkatan yang tajam baik komitmen maupun kemampuan namun indikator kinerja belum tercapai. Maka diputuskan melaksanakan perencanaan siklus III.
Memperhatikan hasil-hasil wawancara dengan guru, bahwa motivasi mulai meningkat dan guruguru merasakan telah menemukan pola dalam menyusun RPP Inovatif, maka kegiatan dilaksanakan secara mandiri, dengan waktu hanya 1 minggu.

Kunci keberhasilan pada siklus II adalah penggunaan Pola Inovatif : Strategi $\rightarrow$ Model Pembelajaran, untuk mendukung strategi diskoveri inkuiri.

Komitmen dan Kemampuan Guru pada Siklus III

1. Nilai Rata-rata Komitmen dan

Persentase dengan nilai 4,00 - 5,00

BHS 4,36=100\%

MIPA $\quad 4,70=\quad 100 \%$

IPS $4,05=88 \%$

TTL $4,31=94 \%$

2. Nilai Rata-rata Kemampuan dan Persentase dengan nilai 4,00 - 5,00

BHS 4,29 $=100 \%$

MIPA $4,53=100 \%$

IPS $4,16=75 \%$

TTL $4,30=88 \%$

Keterangan :

$\mathrm{BHS}=$ rumpun bahasa

MIPA = rumpun MIPA

IPS = rumpun IPS

$\mathrm{TTL}=$ total

Komitmen guru-guru

Kegiatan pada siklus III adalah kegiatan mandiri. Bimbingan yang dilakukan adalah individual, 
lebih banyak kepada guru-guru yang mengalami kesulitan. Pada siklus III peningkatan komitmen terus terjadi, bahkan guru-guru yang mencapai nilai 4,00-5,00 meningkat menjadi $94 \%$.

Jadi indikator kinerja: sebanyak $85 \%$ guru memperoleh nilai komitmen 4,00-5,00 tercapai pada siklus III dengan pencapaian $94 \%$.

Kemampuan guru-guru

Peningkatan kemampuan juga terjadi walau tidak sebesar siklus II. Bahkan, ada 6 orang guru ( = $32 \%$ ) tidak mengalami peningkatan. Tetapi, sejak siklus II guru-guru tersebut telah mencapai nilai 4,005,00 pada skala 1-5. Guru-guru dengan nilai 4,00-5,00 mencapai $88 \%$.

Jadi indikator kinerja : sebanyak $85 \%$ guru memperoleh nilai kemampuan 4,00-5,00 tercapai pada siklus III dengan pencapaian $88 \%$.

\section{SIMPULAN}

Dari hasil-hasil yang dipaparkan pada Bab IV, dapat dibuat simpulan bahwa hipotesis tindakan telah terbukti, Kegiatan Kerja Praktek dengan teknik Umpan Balik, terbukti dapat meningkatkan komitmen guru-guru SD NEGERI 165726 Tebing Tinggi dalam menyusun RPP Inovatif.

Indikator kinerja : Sekurangkurangnya $85 \%$ guru menunjukkan komitmen yang baik dalam menyusun RPP Inovatif (nilai ratarata 4,00-5,00) dalam skala 1-5, tercapai pada akhir siklus III dengan pencapaian $94 \%$.

Atas hasil-hasil yang dicapai dalam penelitian ini, penulis rekomendasikan kepada pihak-pihak yang terkait dengan upaya peningkatan mutu pendidik yaitu :

a. Para Kepala Sekolah, untuk merevisi cara-cara peningkatan mutu pendidik, dari model ekspos fakto menjadi bentuk kerja praktek nyata secara berkelanjutan. Model-model ekspos fakto yang banyak dilakukan sebelumnya, terbukti tidak mampu memberdayakan guru-guru.

b. Para Pengawas Pendidikan, bahwa peningkatan mutu pendidik bukan suatu hal yang sederhana. Perlu upaya berkelanjutan untuk melaksanakan supervisi, agar pola pembelajaran guru-guru tidak kembali lagi pada pola konvensional, karena pola tersebut tidak sesusai dengan Peraturan Menteri Pendidikan Nasional No.41 tahun 2007.

\section{DAFTAR RUJAKAN}

Badan Standar Nasional Pendidikan. 2006. Panduan Penyusunan Kurikulum

Tingkat Satuan Pendidikan. Jakarta : BSNP.

Bulletin Kent Mathematics Project (1990). Depdikbud. 1992. Buku Pedoman 
Betti: Peningkatan Kinerja Guru ...

Penyelenggaraan

Musyawarah Guru Mata

Pelajaran.

Depdikbud.

Depdikbud. 1993. Dengan

Pemantapan Kerja Guru Kita

Siapkan Sumber Daya

Manusia yang Berkualitas

Untuk Menyongsong

Pembangunan Jangka

Panjang Tahap II. Jakarta :

Depdikbud.

Depdiknas. 2003. Kurikulum

Berbasis Kompetensi. Jakarta

: Depdiknas. Depdiknas.

2005. Peraturan Pemerintah

Nomor 19 tahun 2005 tentang

Standar Nasional Pendidikan.

Jakarta : Depdiknas.

Depdiknas. 2007. Peraturan Menteri

Pendidikan Nasional No. 16

tahun 2007 tentang

Kualifikasi Akademik dan

Kompetensi Guru. Jakarta :

Depdiknas.

Depdiknas. 2007. Peraturan Menteri Pendidikan Nasional No.41 tahun 2007 Tentang Standar

Proses Pendidikan Dasar dan

Menengah. Jakarta :

Depdiknas.

Dirjen Pendidikan Tinggi. 2007.

Panduan Penyusunan

Perangkat Portofolio

Sertifikasi Guru Dalam

Jabatan. Jakarta : Depdiknas.
Direktorat Dikmenum. 1999. Manajemen Peningkatan Mutu Berbasis Sekolah. Jakarta : Depdiknas.

Direktorat Pembinaan SMA. 200X. Perangkat Penilaian KTSP. Jakarta : Depdiknas.

Direktorat Pembinaan SMA. 200X. Perangkat Pembelajaran KTSP. Jakarta : Depdiknas.

Echol, John M \& Hassan Shadily. 1984. Kamus InggrisIndonesia. Jakarta : Gramedia.

Imron, Ali. 1995. Pembinaan Guru di Indonesia. Malang : Pustaka Jaya.

Kartono, Kartini. 1992. Psikologi Wanita, Jilid I. Bandung : CV. Mandar Maju. 